\title{
Influence of inhibitors on increase in intracellular free calcium and proliferation induced by platelet-activating factor in bovine oviductal cells
}

\author{
U. Tiemann' ${ }^{1}$ P. Neels ${ }^{2}$, R. Pöhland ${ }^{1}$, H. Walzel ${ }^{2}$ and B. Löhrke ${ }^{3}$ \\ ${ }^{1}$ Unit of Reproductive Biology and ${ }^{3}$ Unit of Population Biology of Research Institute for the Biology of Farm Animals, \\ Dummerstorf, Germany; and 'Department of Medical Biochemistry, University of Rostock, Germany
}

\begin{abstract}
Oviductal endosalpingeal cells were isolated mechanically from heifers and cultured until there was $100 \%$ confluency. The cells were loaded with the $\mathrm{Ca}^{2+}$-sensitive fluorochrome, fura-2/acetoxymethylester, and cytosolic free calcium $\left(\left[\mathrm{Ca}^{2+}\right]_{\mathrm{i}}\right)$ was monitored by spectrofluorimetry. Platelet-activating factor, at a concentration of $30 \mathrm{nmol} \mathrm{l}^{-1}$, induced an intracellular $\mathrm{Ca}^{2+}$ increase in cultured bovine oviductal cells, mainly via influx from the extracellular space. In fura-2-loaded oviductal cells, different $\mathrm{Ca}^{2+}$ channel blockers were investigated to characterize the pathways responsible for the $\mathrm{Ca}^{2+}$ influx. The negative effects of $\mathrm{Ni}^{2+}, \mathrm{La}^{3+}$ - and $\mathrm{Ca}^{2+}$-activated $\mathrm{K}^{+}$channel blockers, such as apamin and charybdotoxin, and $\mathrm{Ca}^{2+}$ channel blockers, such as dotarizine, on the platelet-activating factor-induced $\left[\mathrm{Ca}^{2+}\right]_{\mathrm{i}}$ increase indicate the minor participation of the voltage-gated $\mathrm{Ca}^{2+}$ channels. TMB- 8 and flufenamic acid blocked the plateletactivating factor-induced $\mathrm{Ca}^{2+}$ increase directly on non-selective cationic channels or acted via a Ca ${ }^{2+}$ release-triggered $\mathrm{Ca}^{2+}$ influx. Platelet-activating factor, at concentrations of $1.25 \mathrm{\mu mol} \mathrm{l}^{-1}$ and $2.5 \mathrm{\mu mol} \mathrm{l}^{-1}$, significantly stimulated the proliferation and depolarization of oviductal cells, but $10 \mu \mathrm{mol}^{-1}$ significantly decreased both parameters and exerted a cytotoxic effect on cells. After incubation with TMB-8 or flufenamic acid, the cell proliferation was inhibited in a concentration-dependent manner, with $\mathrm{IC}_{50}$ values of $26.57 \mu \mathrm{mol} \mathrm{l}^{-1}$ and $95.29 \mu \mathrm{mol} \mathrm{l}^{-1}$, respectively. The depolarization was significantly inhibited at $50 \mu \mathrm{mol} \mathrm{l}^{-1}$ for both TMB- 8 and flufenamic acid. The results of the present study may contribute to further understanding of the mechanism behind the actions of platelet-activating factor on oviductal cells.
\end{abstract}

\section{Introduction}

The oviduct is the site of many events involved in mammalian reproduction, including gamete transport, fertilization, early embryonic development and embryo transport. Morphological and functional changes occur in oviductal ciliary activity, which plays a central role in ampullary transport of the ova or early embryo and is under the control of steroids (Nozaki and Ito, 1987) and humoral factors, such as platelet-activating factor (PAF). Studies by Velasquez et al. (1995) indicate that the administration of PAF to cyclic hamsters hastens transport of their oocytes. Furthermore, Hermoso and Villalon (1995) reported that the ciliary beat of hamster oviductal ciliated cells in vitro is increased by the addition of PAF at concentrations from 20 to $200 \mathrm{nmol}^{-1}$, indicating that the earlier passage of embryos to the uterus may be mediated by PAF. Yang et al. (1992) detected the presence of PAF receptors in the oviductal membranes of rabbits during early pregnancy using a

Resubmitted manuscript received 1 September 1998. radioligand binding assay. PAF plays a significant paracrine role in stromal-epithelial cell interactions in the uterus during the implantation process (Harper, 1989), but its physiological role in oviduct function is unclear. Tiemann et al. (1996) reported that PAF induces a transient increase in intracellular $\mathrm{Ca}^{2+}$ concentration $\left[\mathrm{Ca}^{2+}\right]_{i}$, which may have a significant effect on cell function. PAF had a stimulatory effect on the proliferation of bovine endothelial cells (Lin and Rui, 1994), human endometrial HEC-1B cells (Ahmed et al., 1994), and bovine endometrial stromal cells (Tiemann et al., 1995). Previous studies showed that a PAF-induced increase in $\left[\mathrm{Ca}^{2+}\right]_{i}$ in oviductal cells was, for the most part, suppressed by a $\mathrm{Ca}^{2+}$-free solution, indicating that the response is mostly dependent on $\mathrm{Ca}^{2+}$ influx from extracellular sources (Tiemann et al., 1996). The mechanism by which PAF increases calcium influx in oviductal cells is not yet clear. Extracellular calcium is thought to enter cells through calcium-specific plasma membrane channels sensitive to receptor or voltage gating (Olsen et al., 1989; Triggle, 1990; Tsien, 1990). PAF seems to play a role in this process since exposure of oviductal cells to PAF leads to rapid and marked 
intracellular increase in free calcium. However, the voltagesensitive $\mathrm{Ca}^{2+}$ channel classical antagonist, verapamil, had no effect on the PAF-induced increase in $\left[\mathrm{Ca}^{2+}\right]_{i}$ (Tiemann et al., 1996). Since a $\mathrm{Ca}^{2+}$-activated $\mathrm{K}^{+}$-channel is present in the apical membrane of rabbit oviduct, as reported by James and Okada (1994), it is hypothesized that PAF exerts its effect on changes in $\left[\mathrm{Ca}^{2+}\right]_{i}$ and, as a corollary, on the proliferation of $\left[\mathrm{Ca}^{2+}\right]_{i}$ via verapamil non-sensitive channels. This hypothesis was investigated using inhibitors and the measurement of their effects on the change of $\left[\mathrm{Ca}^{2+}\right]_{i}$ in oviductal cells. Furthermore, PAF may act via ion channels responsible for the total transmembrane potential difference and proliferation in intact cells. The transmembrane potential difference and proliferation in reaction to PAF and inhibitors that influenced the PAF effect were examined to obtain information about these processes. In certain cell types, the increase in $\left[\mathrm{Ca}^{2+}\right]_{\mathrm{i}}$ leads to specific responses, such as DNA synthesis and proliferation (Gregory and Kern, 1978; Popper and Batra, 1988; Humes and Cielinski, 1991). PAF is mitogenic for guinea-pig bone marrow cells (Kato et al, 1988), rat mesangial cells (Montero et al., 1993), mouse embryos (Roberts et al., 1993) and bovine endometrial stromal cells (Tiemann et al., 1995).

Oviductal cells were pretreated with the following to elucidate the pathway responsible for the $\mathrm{Ca}^{2+}$ influx: (i) $\mathrm{Ni}^{2+}$ and $\mathrm{La}^{3+}$, which are known to block the influx of extracellular calcium through plasma membrane calcium channels (Triggle, 1990; Tsien, 1990; Lester, 1991); (ii) dotarizine (1-(diphenylmethyl)-4-1-3(-phenyl-1,3-dioxalen2-il)propyl piperazine), which has the potency to block $\mathrm{Ca}^{2+}$ entry, $\mathrm{Ca}^{2+}$ channel receptors, $\mathrm{Ca}^{2+}$ signals and $\mathrm{Ca}^{2+}$ movements (Tejerina et al., 1993; Czernicki et al., 1996); (iii) flufenamic acid, which is known to block $\mathrm{Cl}^{-}$and nonselective ion channels (Wangemann et al., 1986; Gögelein et al., 1990); (iv) charybdotoxin (CTX), a peptide neurotoxin isolated from scorpion venom, which inhibits $\mathrm{Ca}^{2+}$-activated 'maxi K+' channels (Di Beradino et al., 1993), and apamin, a peptide present in bee venom, which can block $\mathrm{Ca}^{2+}$ activated 'small $\mathrm{K}^{+\prime}$ channels (Blatz and Magleby, 1986); and (v) TMB-8 [8-(diethylamino)octyl-3,4,5,-trimethoxybenzoate], which has inhibitory effects on both calcium influx and calcium release from intracellular stores (Yue $e t$ al., $1991 \mathrm{a}, \mathrm{b})$.

\section{Materials and Methods}

\section{Materials}

Tissue culture supplies, platelet-activating factor, EGTA, Triton X-100, trypsin-EDTA solution, Trypan blue solution, propidium iodide (PI), TMB-8 [8-(N,N-diethylamino)octyl3,4,5,-trimethoxybenzoate)], flufenamic acid, $\mathrm{LaCl}_{3}$ and $\mathrm{NiCl}_{2}$ were obtained from Sigma Chemie $\stackrel{6}{\mathrm{G}} \mathrm{mbH}$ (Deisenhofen). Dotarizine was from Alexis (Läufelfinger). Fura-2/acetoxymethylester (fura-2/AM) was obtained from Boehringer Mannheim Biochemicals (Mannheim). Bis-(1,3dibutylbarbituric acid)trimethine-oxonol $\left[\mathrm{DiBaC}_{4}(3)\right]$, apamin and charybdotoxin were obtained from Molecular Probes (Eugene). All other materials were from Sigma.

\section{Animals}

Dairy heifers from a commercial abattoir were used. The reproductive tract was removed immediately after slaughter and transported on ice to the laboratory.

\section{Oviductal cell preparation and culture}

The isolation of oviductal endosalpingeal cells was carried out mechanically as described by Tiemann and Hansen (1995). Briefly, oviducts collected from heifers were stored in Dulbecco's PBS until processing. Oviducts were separated from connective tissue and the fimbria was removed. Each oviduct was then stripped of endosalpingeal cells by moving the forceps from the utero-tubal junction towards the infundibulum. The endosalpingeal cells were extruded by opening the infundibulum and then were washed three times in TCM-199 supplemented with 1\% (v/v) antibiotic-antimycotic (ABAM). Cells from each heifer were cultured separately. Viability, determined by Trypan blue exclusion, was 95\%. Single and aggregated oviductal cells (approximately $2 \times 10^{6}$ cells $\mathrm{ml}^{-1}$, as determined by haemocytometer counting) were cultured in $80 \mathrm{~cm}^{2}$ tissue culture flasks (Greiner, Frickenhausen). The cells were cultured until $100 \%$ confluence in TCM-199 with 10\% (v/v) FCS and $1 \%(\mathrm{v} / \mathrm{v}) \mathrm{ABAM}$ at $37^{\circ} \mathrm{C}$ in humidified air $\left(5 \% \mathrm{CO}_{2}\right)$. The medium was changed every 2 days. After 6-8 days of culture, the adherent cells were gently washed twice with incomplete Hank's balanced salt solution (HBSS) without $\mathrm{Ca}^{2+}$ and $\mathrm{Mg}^{2+}$. Ten millilitres of trypsin-EDTA $(0.02-0.05 \%)$ in incomplete HBSS was then added and kept at $37^{\circ} \mathrm{C}$ for 20-30 min. FCS (final concentration $10 \%$, v/v) was added to the cell suspension. The cells were washed twice with PBS and resuspended in RPMI 1640 medium for the determination of $\left[\mathrm{Ca}^{2+}\right]_{i}$, or in TCM-199 for the detection of the transmembrane potential difference changes and in cell proliferation assays.

\section{Measurements of intracellular calcium}

The fluorescence of the fura-2-loaded oviductal cells was measured with a spectrofluorometer (Shimadzu RF-5001 PC). Briefly, the cells were loaded with fura-2/AM (final concentration, $2 \mu \mathrm{mol} \mathrm{l}^{-1}$ ) in RPMI 1640 medium under gentle shaking in the dark at room temperature for $45 \mathrm{~min}$. The cells were centrifuged $\left(500 \mathrm{~g}\right.$ for $3 \mathrm{~min}$ at $4^{\circ} \mathrm{C}$ ) and washed three times in sodium-Hepes buffer, pH 7.4. Furaloaded cells $\left(2 \times 10^{6}\right)$ were transferred to a thermostatic quartz cuvette and stirred continuously at $37^{\circ} \mathrm{C}$. After equilibration $\left(5 \mathrm{~min}, 37^{\circ} \mathrm{C}\right)$, each agonist was pipetted directly into the cell suspension before addition of PAF. Fura2-loaded cells were preincubated with apamin for $50 \mathrm{~s}$, TMB$8, \mathrm{LaCl}_{3}$, or $\mathrm{NiCl}_{2}$ for $2 \mathrm{~min}$, flufenamic acid for $5 \mathrm{~min}$, charybdotoxin for $15 \mathrm{~min}$, and dotarizine for $90 \mathrm{~min}$ before the addition of PAF. PAF was added at a final concentration of $30 \mathrm{nmol} \mathrm{l}^{-1}$. Fluorescence was excited at 340 and $380 \mathrm{~nm}$ using a rotating filter wheel, and the emission was measured at $490 \mathrm{~nm}$. The fluorescence intensities of the ratio $340: 380$ 
were used for calculating the concentrations of $\left[\mathrm{Ca}^{2+}\right]_{i}$ as described by Tiemann et al. (1996).

\section{Detection of transmembrane potential difference}

Changes in transmembrane potential differences were described using the oxonol dye $\mathrm{DiBaC}_{4}(3)$ as an indicator (Löhrke et al., 1995). The negatively charged oxonol is repelled from intact cells with high transmembrane potential (Löhrke et al., 1997). In depolarizing the cells, the fluorescence intensity increases proportionally to the decrease of the transmembrane potential difference, as has been described for a variety of cell types (Rink et al., 1980).

The cells in monolayer were treated without and with different concentrations of PAF $(0,1.25,2.5,5$ and $\left.10 \mu \mathrm{mol} \mathrm{l}^{-1}\right)$, TMB- $8\left(0,2.5,5,10,20,50\right.$ and $\left.100 \mu \mathrm{mol} \mathrm{l}^{-1}\right)$ or flufenamic acid $\left(0,5,10,20,50\right.$ and $\left.100 \mathrm{mmol} \mathrm{l}^{-1}\right)$ in serumfree TCM-199 medium for $24 \mathrm{~h}$. The adherent cells were washed gently twice with HBSS without $\mathrm{Ca}^{2+}$ or $\mathrm{Mg}^{2+}$. Then trypsin-EDTA in HBSS was added. After 20-30 min, the cells were washed twice with PBS and resuspended in PBS. The cells were incubated with $\mathrm{DiBaC}_{4}(3)$ in PBS at a final concentration of $0.25 \mathrm{\mu mol}^{-1}$ at $37^{\circ} \mathrm{C}$ for $30 \mathrm{~min}$, and then the cells were washed twice with PBS. In cells with insidenegative potentials, the negatively charged oxonol dye is excluded from cells as their transmembrane potential becomes more negative. In a calibration experiment, the oviductal cells were equilibrated by buffer solution (156 $\mathrm{mmol} \mathrm{l}^{-1} \mathrm{NaCl}, 5 \mathrm{mmol} \mathrm{l}^{-1}$ Hepes). A depolarization effect of cells was detected by iso-osmotically varying the extracellular $\mathrm{K}^{+}$concentration (60 and $100 \mathrm{mmol}^{-1} \mathrm{KCl}$ ). In comparison with the control, the depolarization increased to $117 \%$ at $60 \mathrm{mmol} \mathrm{KCl}^{-1}$ and to $146 \%$ at $100 \mathrm{mmol} \mathrm{KCl}^{-1}$. The viability of cells was assayed by the propidium iodide (PI) exclusion test. PI was added to the cell suspension at a final concentration of $40 \mathrm{\mu mol} \mathrm{l}^{-1}$ for $5 \mathrm{~min}$ at room temperature (Löhrke et al., 1995), and then the cells were washed twice with PBS.

The fluorescence was imaged by an Diaphot 200 (Nikon) microscope using an $100 \mathrm{~W}$ mercury lamp and an epifluorescence filter block with $450-490 \mathrm{~nm}$ (excitation)$510 \mathrm{~nm}$ (dichroid mirror) $-520 \mathrm{~nm}$ long pass (emission). Images $(512 \times 512 \times 24 \mathrm{bit})$ were grabbed and analysed using a chilled colour CCD-camera (C5310, Hamamatsu), a RGBframe grabber (MVP, Matrox), a PC (Pentium ${ }^{\oplus}$, Windows 95 $5^{\circ}$ ) and image analysis software (analysis $2.01^{\oplus}$, SIS). The total area of cells was measured for each fluorescence image using a phase-contrast picture of the same frame and automatic detection of objects with analySIS ${ }^{\circledast}$. The corresponding fluorescence image was separated into two grey value pictures using the red and green intensities. In these two images, the stained areas and the mean values of intensities in the stained areas were monitored automatically.

\section{Proliferation}

Cells were plated at $2 \times 10^{-4} \mathrm{ml}^{-1}$ (24-well plate) in TCM199 and $1 \%(\mathrm{v} / \mathrm{v})$ ABAM with different concentrations of PAF

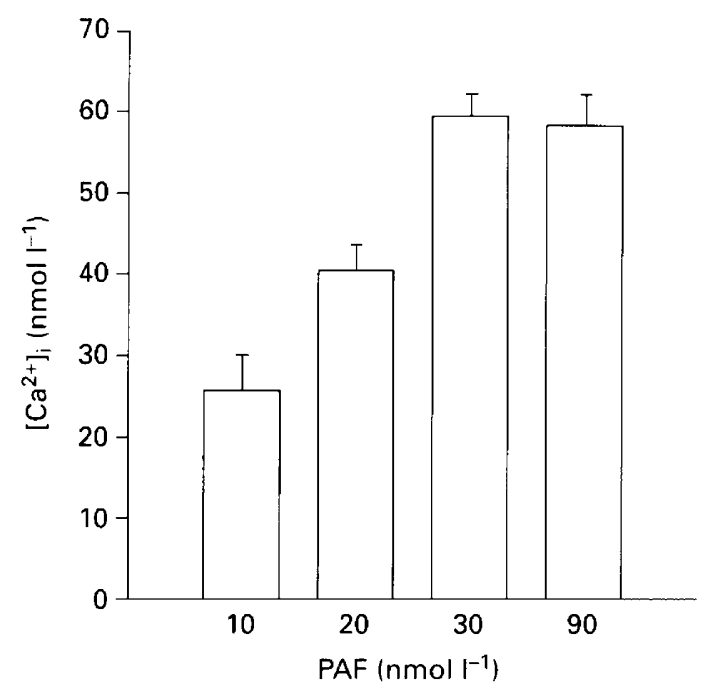

Fig. 1. Platelet-activating factor (PAF)-induced intracellular $\mathrm{Ca}^{2+}$ $\left(\left[\mathrm{Ca}^{2+}\right]_{i}\right)$ increase in fura-2-loaded bovine oviductal cells. Each value is the mean $\pm \mathrm{SD}$ of two experiments.

$\left(0,1.25,2.5,5\right.$ and $\left.10 \mu \mathrm{mol}^{-1}\right)$, TMB- $8(0,2.5,5,10,20,50$ and $\left.100 \mathrm{~mol} \mathrm{l}^{-1}\right)$ or flufenamic acid $(0,5,10,20,50,100$ and $\left.200 \mathrm{mmol} \mathrm{l}^{-1}\right)$ in duplicate. After $48 \mathrm{~h}$, the monolayers were washed with HBSS and then harvested by trypsin-EDTA as described above and dispersed into $0.9 \%(\mathrm{v} / \mathrm{v}) \mathrm{NaCl}$ solution. Proliferative cell growth was determined by electronic particle counting (Coulter Counter Multisizer II).

The permeability of cells exposed to different concentrations of PAF, TMB-8 or flufenamic acid was assayed by Trypan blue exclusion test. Vital cells exclude the stain.

\section{Statistical analysis}

The experiment was run in sets of three or four for each oviductal cell preparation. Data are expressed as mean \pm SD. Pairwise comparisons between treated and the corresponding controls were performed, using one-factor analysis of variance (ANOVA) and a Student-Newman-Keuls test to determine significant differences $(P<0.05)$. The relative data were transformed with SAS statistical software for estimation of $\mathrm{IC}_{50}$ values. The transforming model was the 'three parametric log transforming model'.

\section{Results}

\section{$\mathrm{Ca}^{2+}$ response}

Addition of PAF to the fura-2-loaded bovine oviductal cells resulted in an increase in fluorescence, indicative of a $\left[\mathrm{Ca}^{2+}\right]_{i}$ increase. PAF at concentrations of 30 or $90 \mathrm{nmol} \mathrm{l}^{-1}$ induced increases in $\left[\mathrm{Ca}^{2+}\right]_{i}$ in approximately the same range (Fig. 1). At PAF concentrations of $10 \mathrm{nmol}^{-1}$ and $20 \mathrm{nmol} \mathrm{l}^{-1}$, the $\left[\mathrm{Ca}^{2+}\right]_{i}$ increase was markedly reduced. The original trace of $\left[\mathrm{Ca}^{2+}\right]_{\mathrm{i}}$ for 10,30 and $90 \mathrm{nmol}{ }^{-1} \mathrm{PAF}$ is shown (Fig. 2). The 

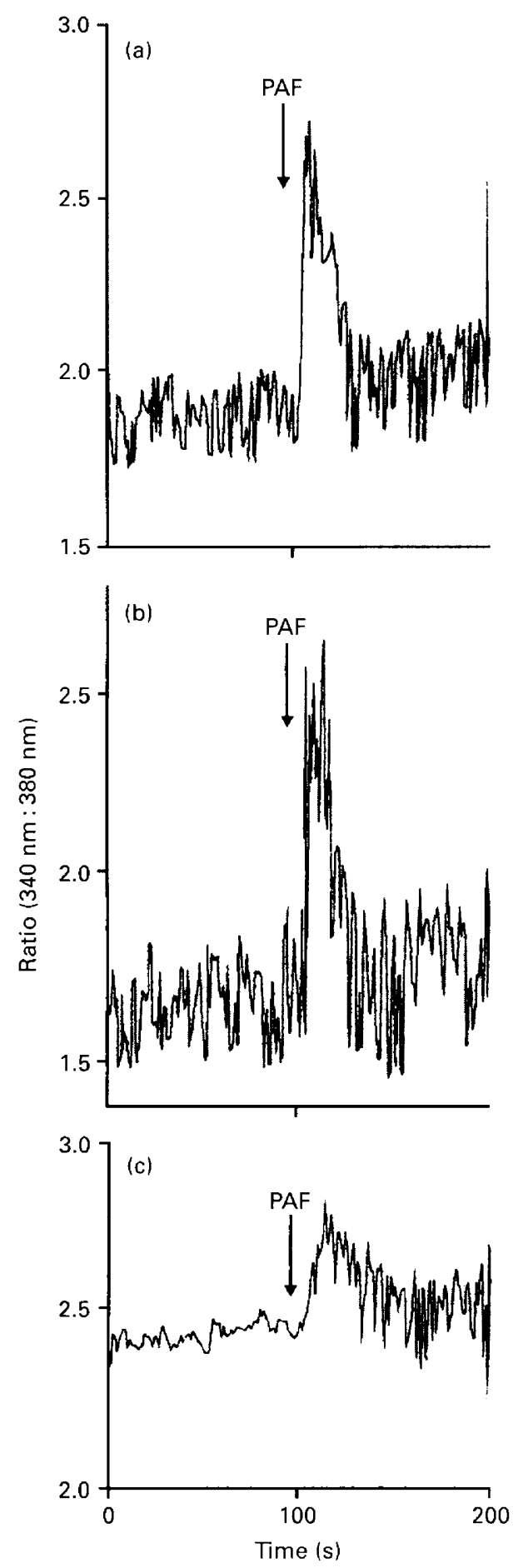

Fig. 2. Original trace of intracellular $\mathrm{Ca}^{2+}\left(\left[\mathrm{Ca}^{2+}\right]_{\mathrm{i}}\right)$ in fura-2-loaded bovine oviductal cells exposed to different concentrations of platelet-activating factor (PAF): (a) $90 \mathrm{nmol} \mathrm{l}^{-1}$, (b) $30 \mathrm{nmol} \mathrm{l}^{-1}$ and (c) $10 \mathrm{nmol} \mathrm{l}^{-1}$.

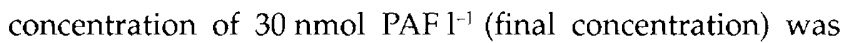
used in the experiments with oviductal cells. Preincubation of the fura-2-loaded cells for $2 \mathrm{~min}$ with $\mathrm{La}^{3+}\left(10 \mu \mathrm{mol} \mathrm{l}^{-1}\right.$ final concentration) or $\mathrm{Ni}^{2+}\left(20 \mu \mathrm{mol}^{-1}\right.$ final concentration) did not inhibit the PAF-induced $\mathrm{Ca}^{2+}$ response (Fig. 3; representative picture for $\mathrm{Ni}^{2+}$ ). Preincubation of the cells

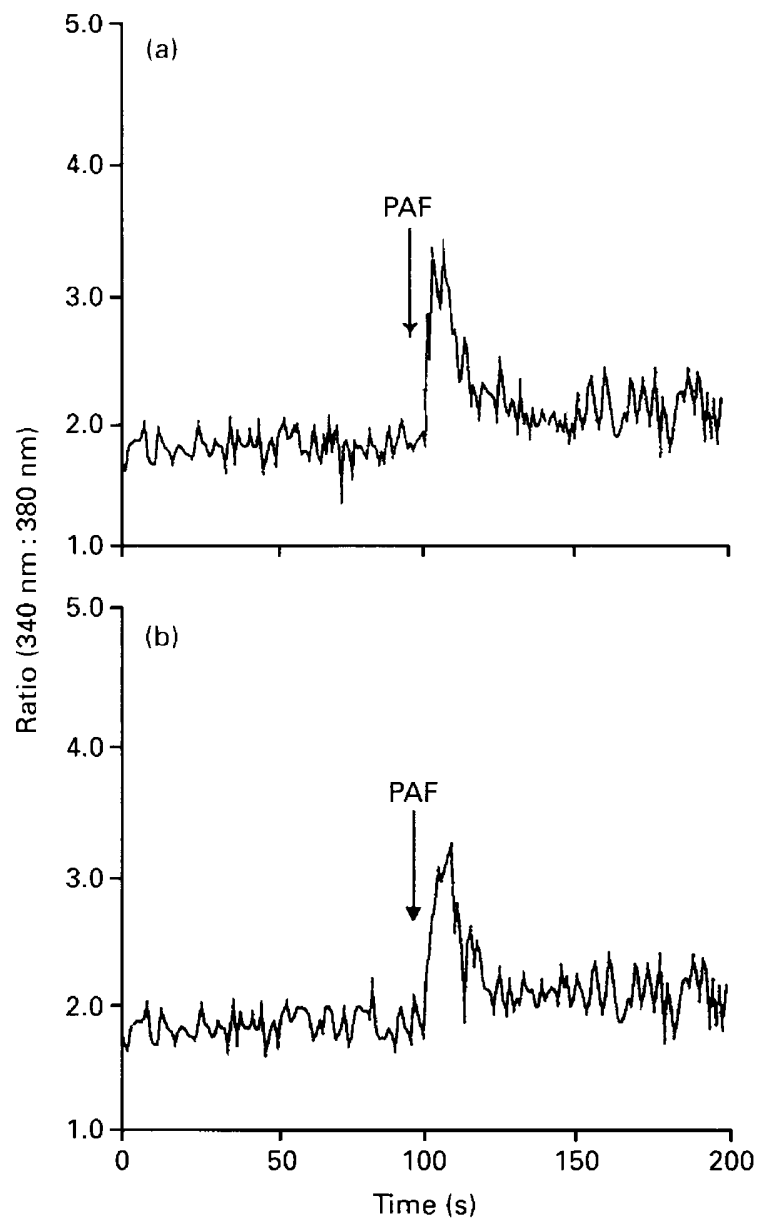

Fig. 3. Representative tracing from three experiments showing no effect of $20 \mu \mathrm{mol} \mathrm{Ni}{ }^{2+} 1^{-1}$ on platelet-activating factor (PAF)-induced intracellular $\mathrm{Ca}^{2+}\left(\left[\mathrm{Ca}^{2+}\right]_{i}\right)$ in fura-2-loaded cultured bovine oviductal cells. The cells were incubated (a) without or (b) with $\mathrm{Ni}^{2+}$ (final concentration, $20 \mathrm{\mu mol}^{-1}$ ) for 2 min before the addition of PAF (final concentration, $30 \mathrm{nmol}^{-1}$ ).

with apamin (0.1 or $0.2 \mu \mathrm{mol} \mathrm{l}^{-1}$ final concentration) (Fig. 4) and charybdotoxin $\left(10 \mathrm{nmol} \mathrm{l}^{-1}\right.$ final concentation) failed to inhibit PAF-induced $\left[\mathrm{Ca}^{2+}\right]_{\text {in }}$ in oviductal cells. The addition of dotarizine $\left(100 \mathrm{nmol}^{-1}\right)$ before the addition of PAF did not inhibit the $\mathrm{Ca}^{2+}$ response (data not shown). The PAF-induced $\left[\mathrm{Ca}^{2+}\right]_{i}$ increase was reduced by TMB- 8 in a dose-dependent manner. The increase of $\left[\mathrm{Ca}^{2+}\right]_{i}$ caused by $30 \mathrm{nmol} \mathrm{PAF} \mathrm{l}^{-1}$ alone was $73.65 \pm 17.07 \mathrm{nmol} \mathrm{l}^{-1}$. After preincubation of the cells with TMB- 8 for $2 \mathrm{~min}$, the PAF-induced $\mathrm{Ca}^{2+}$ increase was reduced in the following manner. With TMB- 8 at concentrations of 5,10 and $20 \mathrm{mmol} \mathrm{l}^{-1}$, the increase was significantly reduced to $23.3 \pm 2.8 \%, 15.5 \pm 2.5 \%$ and $6.9 \pm$ $3.2 \%(P<0.05 ; n=3)$, respectively. After 5 min preincubation with $20 \mu \mathrm{mol}$ TMB- $8 \mathrm{l}^{-1}$, a cytotoxic effect on cells was not detectable using propidium iodide and $\mathrm{DiBAC}_{4}(3)$ uptake as criteria for cell damage.

The addition of $20 \mu \mathrm{mol}$ flufenamic acid $\mathrm{l}^{-1} 5 \mathrm{~min}$ before the addition of PAF led to the inhibition of the $\mathrm{Ca}^{2+}$ response (Fig. 5c). This effect was not cytotoxic because the DIBAC $_{4}(3)$ and PI staining were the same as in the control. The 


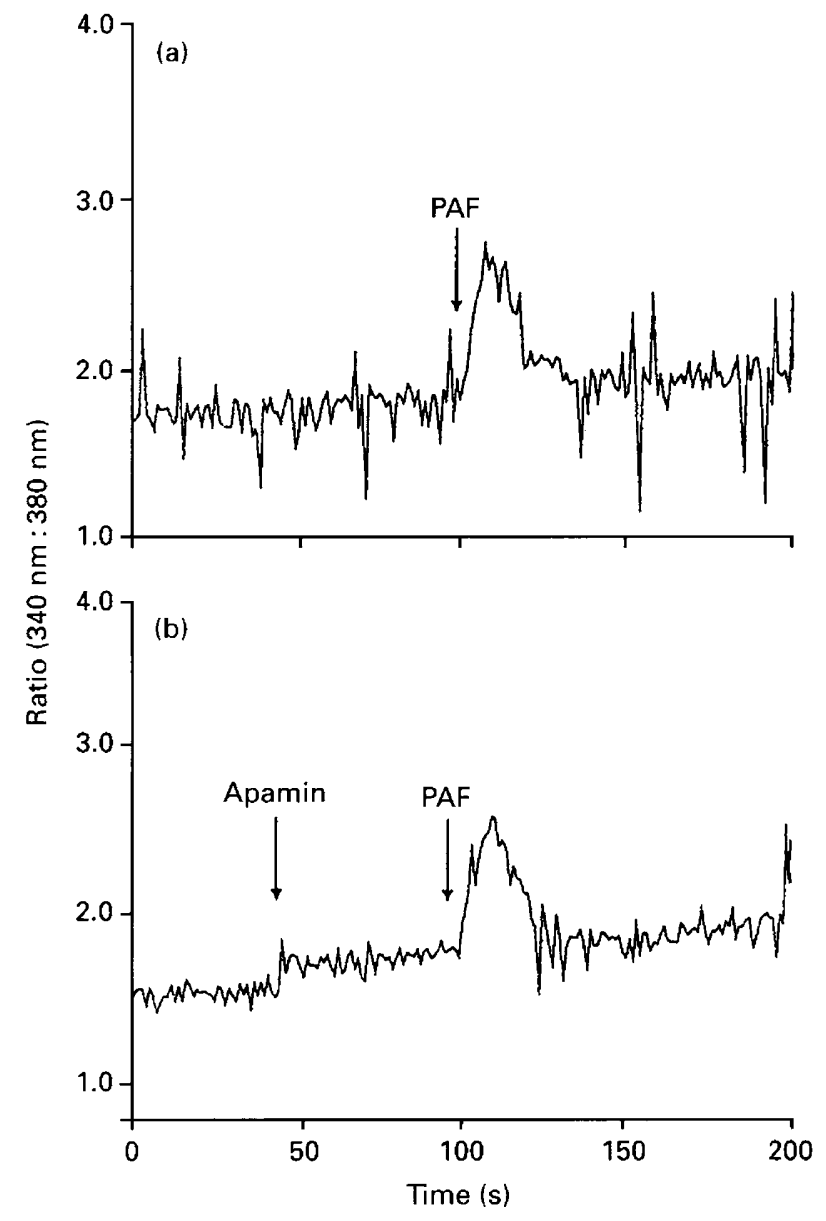

Fig. 4. Representative tracing from three experiments showing no effect of apamin on platelet-activating factor (PAF)-induced intracellular $\mathrm{Ca}^{2+}\left(\left[\mathrm{Ca}^{2+}\right]_{\mathrm{i}}\right)$ in fura-2-loaded cultured bovine oviductal cells. The cells were incubated (a) without or (b) with apamin (final concentration, $0.2 \mu \mathrm{mol} \mathrm{l}^{-1}$ ) for $50 \mathrm{~s}$ before the addition of PAF (final concentration, $30 \mathrm{nmol} \mathrm{l}^{-1}$ ).

inhibition also occurs at concentrations of $10 \mu \mathrm{mol}$ flufenamic acid $\mathrm{l}^{-1}$ (data not shown), but preincubation of cells with 5 mol flufenamic acid $1^{-1}$ resulted in the partial inhibition of the PAF-induced $\left[\mathrm{Ca}^{2+}\right]_{i}$ increase (Fig. $5 \mathrm{~b}$ ) compared with the control (without flufenamic acid, but with 30 nmol PAF $1^{-1}$; Fig. 5a).

\section{Responses of the transmembrane potential}

The changes in the fluorescence intensity of oviductal cells occur after incubation with different concentrations of PAF, TMB-8 or flufenamic acid (Fig. 6). In PAF concentrations of 2.5 and $5 \mu \mathrm{mol} \mathrm{l}^{-1}$, the oviductal cells were significantly depolarized as indicated by the $\operatorname{DiBAC}_{4}(3)$ fluorescence increase (Fig. 7). This depolarization was not accompanied by the cytotoxicity of cells, as the number of cells was not significantly reduced. However, at $10 \mu \mathrm{mol} \mathrm{PAF} \mathrm{l}^{-1}$, the $\mathrm{DiBAC}_{4}(3)$ fluorescence was significantly decreased compared with the control (cells incubated only in medium). This diminution was accompanied by a marked inhibition of the

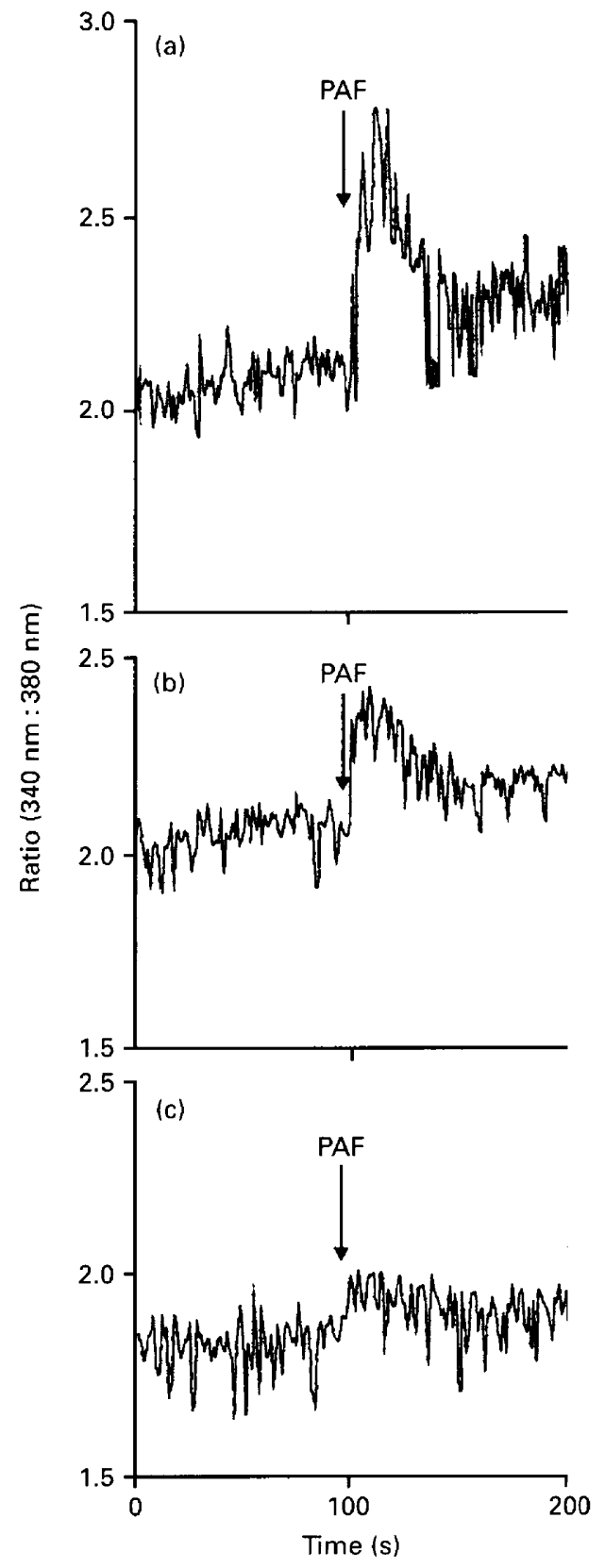

Fig. 5. Effect of adding flufenamic acid to fura-2-loaded cultured bovine oviductal cells. The cells were incubated (a) without, (b) with $5 \mu \mathrm{mol}$ flufenamic acid $\mathrm{l}^{-1}$ (final concentration), or (c) with $20 \mu \mathrm{mol}$ flufenamic acid $1^{-1}$ (final concentration) $5 \mathrm{~min}$ before the addition of $30 \mathrm{nmol}$ platelet-activating factor $(\mathrm{PAF}) \mathrm{l}^{-1}$.

appearance of mitosis (Fig. 8). The concentration of $10 \mu \mathrm{mol}$ PAF $~^{-1}$ caused the cells to detach from the culture plate and the high PI and Trypan blue staining that occurred indicated that the plasma membrane of the cells became permeable to both substances.

At a concentration of $10 \mu \mathrm{mol} T \mathrm{TMB}-8 \mathrm{1}^{-1}$, the $\operatorname{DiBAC}_{4}(3)$ fluorescence of cells increased significantly as compared with the control, indicating depolarization. The depolarization was not indicative of cytotoxicity because the number of cells was approximately in the same range as the control. 

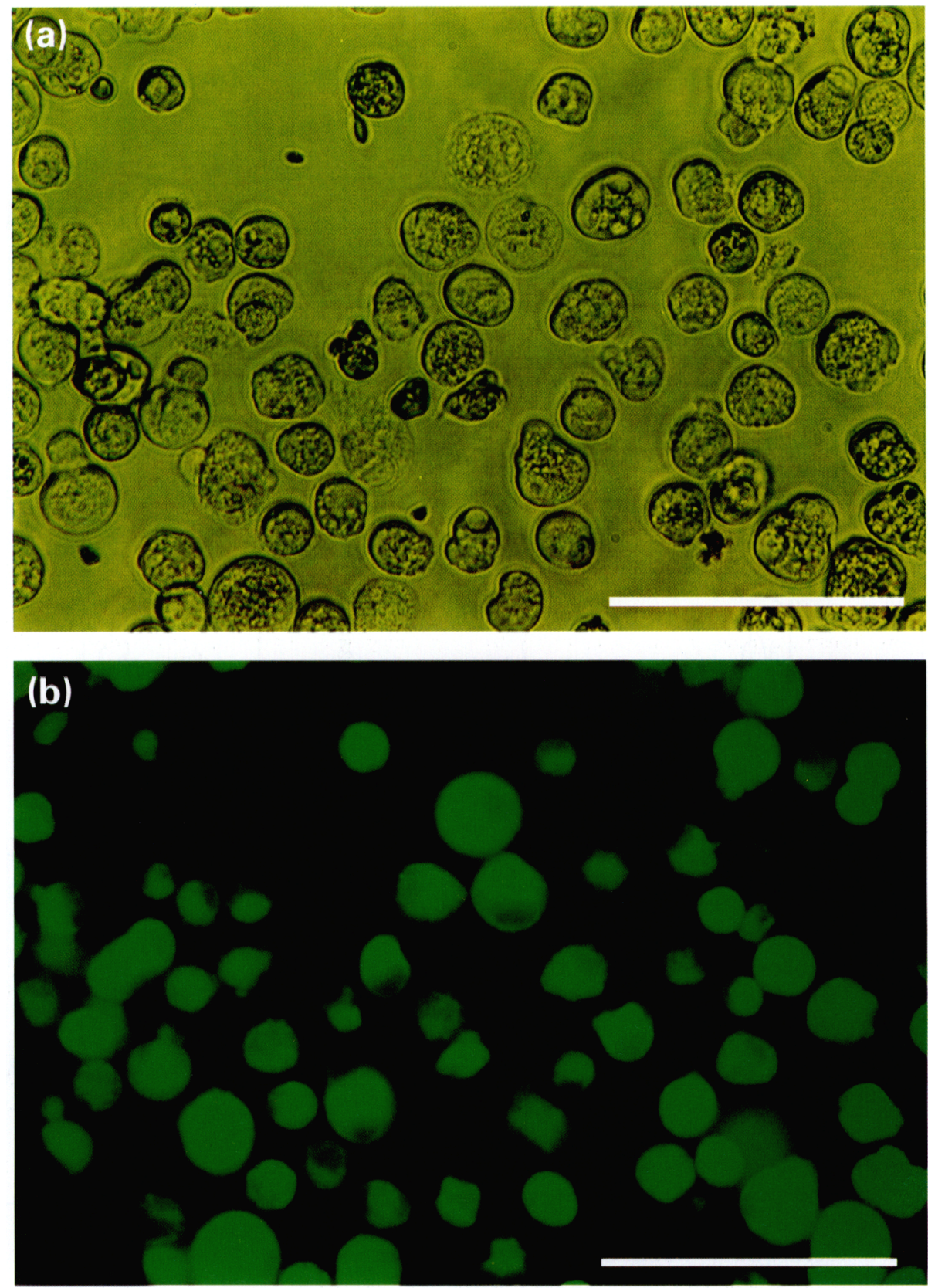

Fig. 6. Typical fluorescence picture of the fluorochrome bis-oxonol ( $\mathrm{DiBAC}_{4}(3)$ ) staining on bovine oviductal cells. (a) Phase-contrast and (b) staining. Scale bars represent $50 \mu \mathrm{m}$.

At $20 \mu \mathrm{mol} T \mathrm{TMB}-8 \mathrm{I}^{-1}$, the $\operatorname{DiBAC}_{4}$ (3) fluorescence of cells began to decrease compared with the control and, at $50 \mu \mathrm{mol}$ TMB- $8 l^{-1}$, the $\operatorname{DiBAC}_{4}(3)$ fluorescence was significantly reduced. At $50 \mu \mathrm{mol}$ TMB- 81 ', the cells began to detach from the culture plate and about $70 \%$ were Trypan blue stained. After incubation of oviductal cells with flufenamic acid, the $\operatorname{DiBAC}_{+}(3)$ fluorescence was significantly increased at $20 \mu \mathrm{mol}$ flufenamic acid $1^{-1}$ compared with the control or to lower concentrations, whereas, at $50 \mu \mathrm{mol}$ flufenamic acid $l^{-1}$, a significant decrease of $\operatorname{DiBAC}_{4}$ (3) fluorescence was observed and $40 \%$ of cells were Trypan blue stained.

\section{Proliferation}

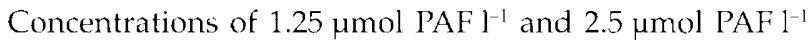
significantly stimulated the proliferation of oviductal cells to $157 \%$ and $127 \%$, respectively, compared with the control (Fig. 8). A concentration of $10 \mu \mathrm{mol} \mathrm{PAF}^{-1}$ significantly decreased the cell proliferation compared with the control. TMB-8 and flufenamic acid had no effect other than cell death. After the $48 \mathrm{~h}$ incubation, TMB- 8 or flufenamic acid inhibited the cell proliferation in a concentration-dependent manner, with an $\mathrm{IC}_{50}$ value of $26.57 \mathrm{\mu mol} \mathrm{l}^{-1}$ and $95.29 \mathrm{\mu mol} \mathrm{l}^{-1}$, respectively. 


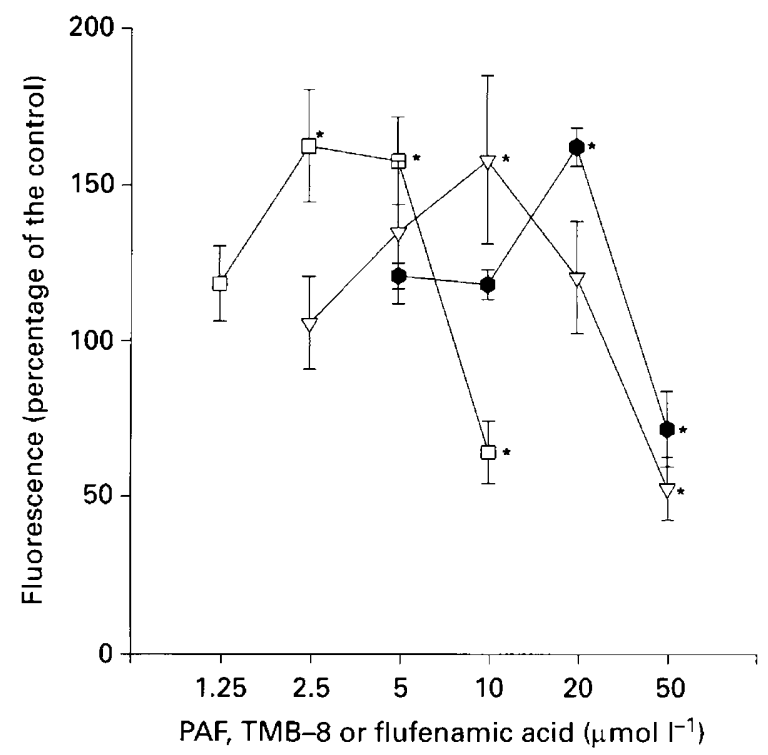

Fig. 7. Effect of platelet-activating factor (PAF) ( $\square$ ), TMB-8 $(\nabla)$, or flufenamic acid ( on transmembrane potential assessed by DiBAC $_{4}(3)$ in cultured bovine oviductal cells after $24 \mathrm{~h}$ treatment. Each value is the mean \pm SD for three experiments performed in duplicate. The fluorescence of the control is considered to be $100 \%$. Significant differences between the control and treatment groups are indicated: ${ }^{*} P<0.05$.

\section{Discussion}

Platelet-activating factor, an inflammatory mediator with potent vascular permeability property, may be the first physiological signal produced by the embryo for the maternal recognition of pregnancy. Mouse and human preimplantation embryos produce PAF (O'Neill, 1985; Smal et al., 1990) and, therefore, PAF is a potential mediator of embryonic signalling to the oviduct. The oviduct is under endocrine control and locally produced factors, such as PAF, play a decisive role in the regulation of oviduct function. Although the effect of PAF on the regulation of oviduct contractility and relaxation, as well as in the ciliary motion of hamster oviduct epithelial cells, has been observed by Hermoso and Villalon (1995), there are few functional studies of the effect of PAF on bovine oviductal cells.

Previous results showed that the increase in $\left[\mathrm{Ca}^{2+}\right]_{i}$ in oviductal cells induced by PAF was reduced when extracellular calcium was depleted, indicating that the effect of PAF on $\left[\mathrm{Ca}^{2+}\right]_{i}$ involves an influx from the extracellular space. The mechanism by which PAF increases calcium influx in oviductal cells is little understood. Oviductal cells were pretreated with different substances to characterize the pathway responsible for the $\mathrm{Ca}^{2+}$ influx. The PAF-induced $\left[\mathrm{Ca}^{2+}\right]_{i}$ increase was not inhibited by pretreatment of cells with $\mathrm{Ni}^{2+}$ and $\mathrm{La}^{3+}$, indicating that the $\mathrm{Ca}^{2+}$ influx is not blocked at the plasma membrane calcium channels. Neither the 'small' nor the 'maxi'- $\mathrm{Ca}^{2+}$-activated $\mathrm{K}^{+}$channels were involved in the PAF-induced $\mathrm{Ca}^{2+}$ influx because charybdotoxin and apamin had no effect on this pathway. In contrast, other cell types (for example, human B lymphoblastoid cells) responded to PAF with a $\left[\mathrm{Ca}^{2+}\right]_{i}$

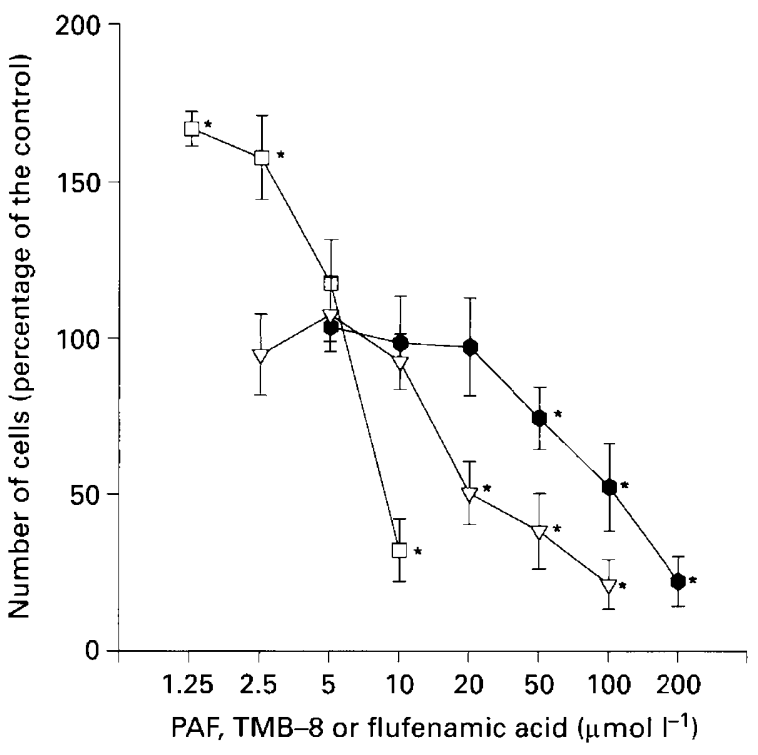

Fig. 8. Effect of platelet-activating factor (PAF) $(\square)$, TMB-8 $(\nabla)$, or flufenamic acid ( ) on proliferation in cultured bovine oviductal cells after $48 \mathrm{~h}$ treatment. Each value is the mean $\pm \mathrm{SD}$ for three experiments performed in duplicate. The fluorescence of the control is considered to be $100 \%$. Significant differences between the control and treatment groups are indicated: ${ }^{*} P<0.05$.

increase by voltage-dependent mechanisms via 'maxi' $\mathrm{K}^{+}$ channels (Di Beradino et al., 1993).

After preincubation of oviductal cells with $20 \mu \mathrm{mol}$ TMB- $8 \mathrm{l}^{-1}$ for $5 \mathrm{~min}$, the PAF-induced increase in $\left[\mathrm{Ca}^{2+}\right]_{i}$ was completely inhibited. This inhibition was not due to a cytotoxic effect. This finding is consistent with the range of dose of TMB-8 $\left(1.8-470.0 \mu \mathrm{mol} \mathrm{l}^{-1}\right)$ required to block responses of skeletal muscle in vitro (Malagoni and Chiou, 1974) and of neurohybrid cells $\left(10-50 \mu \mathrm{mol} \mathrm{l}^{-1}\right)$ to PAF (Yue et al., 1991a,b). The inhibitory effect of TMB-8 on PAFinduced increases in $\left[\mathrm{Ca}^{2+}\right]_{\text {; }}$ of oviductal cells is due largely to an inhibition of plasma membrane calcium influx. This is in agreement with reports showing TMB- 8 inhibition of calcium uptake in adrenal glomerulosa cells (Kojima et al., 1985) and neurohybrid NG108-15 cells (Yue et al, 1991b). However, the exact mechanism of the inhibitory effect of TMB-8 on the cellular response to PAF remains to be clarified. It is possible that TMB-8 displaces calcium from its binding site on the surface membrane, and acts subsequently to stabilize the membrane which prevents calcium influx (Sato, 1992).

In the present study, flufenamic acid at concentrations of 10 and $20 \mu \mathrm{mol} \mathrm{l}^{-1}$ significantly reduced the PAF-mediated $\left[\mathrm{Ca}^{2+}\right]_{\mathrm{i}}$ increase in oviductal cells, whereas $5 \mu \mathrm{mol}$ flufenamic acid $l^{-1}$ partially reduced the $\left[\mathrm{Ca}^{2+}\right]_{i}$ increase, indicating that a non-selective ion channel may be involved in this effect (Wangemann et al., 1986; Gögelein et al., 1990). Flufenamic acid, a $\mathrm{Cl}^{-}$and non-selective cation channel blocker, causes a release of $\mathrm{Ca}^{2+}$ from intracellular stores (Poronnik et al., 1992; Lee et al., 1996) in a manner similar to thapsigargin (Diserbo et al., 1995). In many cell types, the intracellular increase of free $\mathrm{Ca}^{2+}$ is dependent on events linked to $\mathrm{Ca}^{2+}$ release- 
triggered $\mathrm{Ca}^{2+}$ influx (Berridge, 1993). The respective inhibitory effect of flufenamic acid may indicate an important role for the release of intracellular $\mathrm{Ca}^{2+}$ stores in the PAF-induced $\left[\mathrm{Ca}^{2+}\right]_{i}$ increase. This calcium release can activate calcium influx and PAF acts via a $\mathrm{Ca}^{2+}$ releasetriggered $\mathrm{Ca}^{2+}$ influx. It is possible that the PAF receptor is associated with the cationic channel blocked by flufenamic acid. The results reported by Yue et al. (1991b) and Tiemann $e t$ al. (1996) have shown that the PAF-induced $\mathrm{Ca}^{2+}$ influx was mediated through receptor-operated $\mathrm{Ca}^{2+}$ channels, but was not affected by verapamil, a voltage-dependent $\mathrm{Ca}^{2+}$ channel inhibitor. Studies on the effect of flufenamic acid on oviductal cells have not yet been reported to our knowledge. However, in rat mesangial cells, $100 \mu \mathrm{mol}$ flufenamic acid $\mathrm{l}^{-1}$ partially reduced the $\mathrm{H}_{2} \mathrm{O}_{2}$-mediated $\left[\mathrm{Ca}^{2+}\right]_{\mathrm{i}}$ increase (Meyer et al., 1996). In the present study, this concentration of flufenamic acid was cytotoxic for oviductal cells in primary cultures.

The change of transmembrane potential is caused by ion exchange and the change of ion flux modifies the transmembrane potential difference. Inward current through the putative receptor-operated channels could produce appreciable changes in membrane potential. Avdonin et al. (1991) suggested that activators of receptor-operated channels trigger the activation of $\mathrm{Ca}^{2+}$ and $\mathrm{Na}^{+}$currents and, by increasing $\left[\mathrm{Ca}^{2+}\right]_{i}$, the $\mathrm{K}^{+}$efflux is stimulated. The balance between these currents can determine the agonist effect on membrane potential. The present results indicate that PAF causes dose-dependent depolarization in intact oviductal cells. This finding is in agreement with the report by Katnik and Nelson (1991) that membrane potential measurements using the fluorescent dye bis-oxonol revealed a transient membrane depolarization in macrophages concomitant to the increase in $\left[\mathrm{Ca}^{2+}\right]_{i}$ induced by PAF. Channels that are influenced by PAF can be responsible for both the $\mathrm{Ca}^{2+}$ uptake and the transmembrane potential of intact oviductal cells. This fact supports the result obtained with flufenamic acid, that nonselective cationic channels can be activated by PAF, because $\mathrm{Ca}^{2+}$-specific or -selective channels have only a small influence on the transmembrane potential (Wilson and Chused, 1985).

The activation of non-selective cationic channels by PAF can be significant for the proliferation of oviductal cells. The results of the present study indicate that PAF is capable of stimulating the cell division of oviductal cells. In general, calcium uptake seems to play a role in the regulation of proliferation (Whitefield et al., 1976; Hazelton et al., 1979; Shultz and Raij, 1990). How the induced $\mathrm{Ca}^{2+}$ signal is connected with the specific cell responses, for example proliferation, is little understood. Results from other cell systems indicate an important function of $\mathrm{Ca}^{2+}$-dependent activation of protein kinase C (Nishizuka, 1989). The present study shows that the proliferative effect of PAF on oviductal cells may directly involve a membrane depolarization. A consistent change in $\operatorname{DiBAC}_{4}(3)$ fluorescence occurs in a concentration range of $1.25-5.00 \mu \mathrm{mol} \mathrm{l}^{-1}$, in which proliferation was also stimulated. The concentration of $10 \mu \mathrm{mol} \mathrm{PAF}^{-1}$ is unphysiological because it markedly inhibits the proliferative growth of oviductal cells. Changes in bis-oxonol fluorescence at $10 \mu \mathrm{mol} \mathrm{PAF} \mathrm{l}^{-1}$ may be caused by an inhibition of $\mathrm{Na}^{+}-\mathrm{K}^{+}$-ATPase. Mohr and Fewtrell (1987) reported that inhibition of the $\mathrm{Na}^{+}-\mathrm{K}^{+}-\mathrm{ATP}$ ase results in a marked depolarization of cells. Flufenamic acid and TMB-8 at concentrations of about $100 \mu \mathrm{mol} \mathrm{l}^{-1}$ and $20 \mu \mathrm{mol} \mathrm{l}^{-1}$, respectively, are cytototoxic because they inhibit the proliferative growth of oviductal cells to $50 \%$. Desgranges $\mathrm{et}$ al. (1991) reported an $\mathrm{IC}_{50}$ value of about $30 \mu \mathrm{mol}$ TMB- $8 \mathrm{l}^{-1}$ in rat arterial smooth muscle cells, and that the growth of cells was totally inhibited at $80 \mu \mathrm{mol}$ TMB- $81^{-1}$. This finding is in the range of the present results and the cytotoxicity can be caused by non-specific toxic effects, such as reduction of cellular ATP content. Brand and Felber (1984) observed that $50 \mu \mathrm{mol}$ TMB- $8 \mathrm{I}^{-1}$ significantly decreased both the cellular ATP concentration and the mitochondrial membrane potential in rat thymocytes.

The different biological effects of PAF in oviductal cells $\left(\left[\mathrm{Ca}^{2+}\right]_{i}\right.$, transmembrane potential and proliferation) have been obtained at different concentrations of the agonist, indicating that calcium increase is upstream of the proliferation. PAF-mediated calcium signalling and mitogenesis in oviductal cells may be mediated by distinct subtypes of receptors. The present data and those of Kudolo and Harper (1989) in the pregnant rat uterus, and Baldi et al. (1994) and Maggi et al. (1994) in human endometrial cancer cell line HEC-1A, indicate that a low concentration of PAF induces $\left[\mathrm{Ca}^{2+}\right]_{\mathrm{i}}$ via the high-affinity site of the receptor and that a high concentration of PAF induces proliferation via its low-affinity site. Maggi et al. (1994) reported the presence of two populations of PAF receptors with affinity constants in the nanomolar and micromolar range. Preliminary data obtained in flow cytometric experiments with the analysis of double immunofluorescence on oviductal cells indicate that there are two kinds of cell populations that have different amounts of PAF receptor (data not shown). One population was antivimentin-positive ( $55 \%$ of total cells) and was PAF receptor bearing to about $29 \%$ of total cells. The other population was anticytokeratin-positive (20\% of total cells) and $6.9 \%$ of this population was PAF-receptor bearing. It is possible that the two types of cell possess subtypes of PAFreceptors with different affinity constants, one in the nanomolar and one in the micromolar range. However, further investigation of the binding of PAF to its receptor is required.

In summary, the present study demonstrates that the PAFinduced intracellular free $\mathrm{Ca}^{2+}$ in oviductal cells appears to be mediated by PAF activation of non-selective cationic membrane channels and that PAF may act via a $\mathrm{Ca}^{2+}$ releasetriggered $\mathrm{Ca}^{2+}$ influx. In view of the importance of $\mathrm{Ca}^{2+}$ homeostasis in cell functions (for example, in proliferation), the present data contribute to the further understanding of the mechanism of PAF actions on oviductal cells.

\section{References}

Ahmed A, Sage SO, Plevin R, Shaibi MA, Sharkey AM and Smith SK (1994) Functional platelet-activating factor receptors linked to inositol lipid hydrolysis, calcium mobilization and tyrosine kinase activity in the human endometrial HEC-1B cell line Journal of Reproduction and Fertility 101 459-466

Avdonin PV, Cheglakov IB and Tkachuk VA (1991) Stimulation of nonselective cation channels providing $\mathrm{Ca}^{2+}$ influx into platelets by plateletactivating factor and other aggregation inducers European Journal of Biochemistry 198 267-273 
Baldi E, Bonaccorsi L, Finetti G, Luconi M, Muratori M, Susini T, Forti G, Serio $M$ and Maggi M (1994) Platelet-activating factor in human endometrium Journal of Steroid Biochemistry and Molecular Biology 49 359-363

Blatz AL and Magleby KL (1986) Single apamin-blocked Ca-activated K channels of small conductance in cultured rat skeletal muscle Nature $\mathbf{3 2 3}$ 718-720

Brand MD and Felber SM (1984) The intracellular calcium antagonist TMB-8 (8-(N,N-diethylamino)octyl-3,4,5-trimethoxybenzoate) inhibits mitochondrial ATP production in rat thymocytes Biochemical Journal 224 1027-1030

Berridge MJ (1993) Inositol triphosphate and calcium signalling Nature 362 315-325

Czernicki Z, Jurkiewicz J, Bojanowski K, Piechnik S and Cervos-Navarro J (1996) Effects of the calcium channel blockers dotarizine and flunarizine on cerebrovascular reactivity Journal of Neurological Science 143 60-63

Desgranges C, Campan M, Gadeau A-P, Guerineau N, Mollard P and Razaka G (1991) Influence of 8-(N,N-diethylamino)octyl-3,4,5,trimethoxybenzoate (TMB-8) on cell cycle progression and proliferation of cultured arterial smooth muscle cells Biochemical Pharmacology 41 1045-1054

Di Beradino W, Bourget I, Schmid-Antoarchi H and Cousin J-L (1993) Platelet-activating factor activates a $\mathrm{Ca}^{2+}$-dependent $\mathrm{K}^{+}$channel which is not involved in c-fos expression in human B lymphoblastoid cells Cellular Signalling 5 623-631

Diserbo M, Cand F, Ziade M and Verdetti J (1995) Stimulation of plateletactivating factor (PAF) receptors increases inositol phosphate production and cytosolic free $\mathrm{Ca}^{2+}$ concentrations in N1E-115 neuroblastoma cells Cell Calcium 17 442-452

Gögelein H, Dahlem D, Englert HC and Lang H (1990) Flufenamic acid, mefenamic acid and niflumic acid inhibit single non-selective cation channels in the rat exoctine pancreas FEBS 268 79-82

Gregory S and Kern M (1978) Adenosine and adenine nucleotides are mitogenic for mouse thymocytes Biochemical and Biophysical Research Communications 83 1111-1116

Harper MJK (1989) Platelet-activating factor: a paracrine factor in preimplantation stages of development? Biology of Reproduction 40 907-913

Hazelton B, Mitchell B and Tupper J (1979) Calcium, magnesium and growth control in the WI-38 fibroblast cell Journal of Cell Biology 83 487-498

Hermoso MA and Villalon MJ (1995) Embryo-secreted factors increase the frequency of ciliary beat of hamster oviductal ciliated cells in vitro. Biology of Reproduction 52S1 180

Humes DH and Cieslinski (1991) Adenosine triphosphate stimulates thymidine incorporation but does not promote cell growth in primary culture of renal proximal tubule cells Renal Physiology and Biochemistry 14 253-258

James AF and Okada Y (1994) Maxi- $\mathrm{K}^{+}$channels from the apical membranes of rabbit oviduct epithelial cells Journal of Membrane Biology 137 109-118

Katnik C and Nelson DJ (1991) PAF-induced increase in cytosolic calcium and transmembrane current in monocyte-derived macrophages Biophysical Journal $59460-466$

Kato T, Hayashi H, Onozaki K and Inoue K (1988) Augmentation of DNA synthesis in guinea pig bone marrow cells by platelet-activating factor Biochemical and Biophysical Communication $15563-668$

Kojima I, Kojima K and Rasmussen H (1985) Mechanism of inhibitory action of TMB-8 [8-( $N, N$-diethylamino)octyl-3,4,5-trimethoxybenzoate] Biochemical Journal $23287-92$

Kudolo GB and Harper MJK (1989) Characterization of platelet-activating factor binding sites on uterine membranes from pregnant rabbits Biology of Reproduction 41 87-607

Lee RJ, Shaw T, Sandquist M and Partridge LD (1996) Mechanism of action of the non-steroidal anti-flammatory drug flufenamic acid on $\left[\mathrm{Ca}^{2+}\right]$ and $\mathrm{Ca}^{2+}$ activated currents in neurons Cell Calcium 19 431-438

Lester HA (1991) Strategies for studying permeation at voltage-gated ion channels Annual Review of Physiology 53 477-496

Lin A-Y and Rui Y-Ch (1994) Platelet-activating factor induced calcium mobilization and phosphoinositide metabolism in cultured bovine cerebral microvascular endothelial cells Biochimica et Biophysica Acta 1224 323-328

Löhrke B, Wegner J, Viergutz T, Dietl G and Ender K (1995) Flow-cytometric analysis of oxidative and proteolytic activities in tissue-associated phagocytes from normal and hypertrophic muscles Analytical Cellular Pathology 9 281-293

Löhrke B, Derno M, Krüger B, Viergutz T, Matthes HD and Jentsch W (1997) Expression of sulphonylurea receptors in bovine monocytes from animals with a different metabolic rate Pflügers Archive European Journal Physiology $434712-720$
Maggi M, Bonaccorsi B, Finetti G, Carloni V, Muratori M, Laffi G, Forti G, Serio $M$ and Baldi E (1994) Platelet-activating factor mediates an autocrine proliferative loop in the endometrial adenocarcinoma cell line HEC-1A Cancer Reserarch 54 4777-4784

Malagoni MH and Chiou CX (1974) Pharmacological evaluation of a new $\mathrm{Ca}^{2+}$ antagonist, 8-( $\mathrm{N}, \mathrm{N}$-diethylamino-occtyl-3,4,5-trimethoxybenzoate hydrochloride, TMB-8): studies in smooth muscle European Journal of Pharmacology 27 25-33

Meyer TN, Gloy J, Hug MJ, Greger R, Schollmeyer $P$ and Pavenstädt $H$ (1996) Hydrogen peroxide increases the intracellular calcium activity in rat mesangial cells in primary culture Kidney International 49 388-395

Mohr FC and Fewtrell C (1987) IgE receptor-mediated depolarization of rat basophilic leukemia cells measured with the fluorescent probe bis-oxonol Journal of Immunology 138 1564-1570

Montero A, Rodriquez-Barbero A and Lopez-Novoa JM (1993) A role for platelet-activating factor in endothelin-1-induced rat mesangial cell proliferation European Journal of Pharmacology 243 235-240

Nishizuka $Y$ (1989) The familiy of proteinkinase C for signal transduction JAMA 262 1826-1833

Nozaki $M$ and Ito $Y$ (1987) Changes in physiological properties of rabbit oviduct by ovarian steroids American Iournal of Physiology 252 R1059-R1065

Olsen R, Seewald M and Powis G (1989) Contribution of external and internal $\mathrm{Ca}^{2+}$ to changes in intracellular free $\mathrm{Ca}^{2+}$ produced by mitogens in Swiss 3T3 fibroblasts: the role of dihydropyridine sensitive $\mathrm{Ca}^{2+}$ channels Biochemical and Biophysical Research Communications 162 448-455

O'Neill C (1985) Thrombocytopenia: an initial maternal response of fertilization Journal of Reproduction and Fertility 73 567-577

Poronnik P, Ward MC and Cook DI (1992) Intracellular $\mathrm{Ca}^{2+}$ release by flufenamic acid and other blockers of the non-selective cation channel FEBS $296245-248$

Popper LD and Batra S (1993) Calcium mobilization and cell proliferation activated by extracellular ATP in human ovarian tumor cells Cell Calcium 14 209-218

Rink TJ, Montecucco C, Hesketh TR and Tsien RY (1980) Lymphocyte membrane potential assessed with fluorescent probes Biochimica et Biophysica Acta 595 15-30

Roberts C, O'Neill C and Wright L (1993) Platelet-activating factor (PAF) enhances mitosis in preimplantation mouse embryos Reproduction Fertility Development 5 271-279

Sato E (1992) Inhibition of germinal vesicle breakdown of isolated cumulusfree mouse oocytes in culture by a calcium inhibitor, TMB-8 journal of Veterinary Medicine Science 54 605-607

Shultz PJ and Raij L (1990) Inhibition of human mesangial cell proliferation by calcium channel blockers Hypertension 15 176-180

Smal MA, Dziadek M, Cooney SJ, Attard M and Baldo BA (1990) Examination for platelet-activating factor production by preimplantation mouse embryos using a specific radioimmunoassay Journal of Reproduction and Fertility $90419-425$

Tejerina T, Chulia T and Gonzalez P (1993) Effects of dotarizine on ${ }^{45} \mathrm{Ca}^{2+}$ movements and contractile responses in vascular smooth muscle European Journal of Pharmacology $23975-81$

Tiemann U and Hansen PJ (1995) Steroidal and growth factor regulation of $\left[{ }^{3} \mathrm{H}\right]$ thymidine incorporation by cultured endosalpingeal cells of the bovine oviduct In Vitro Cellular and Developmental Biology 31 640-645

Tiemann U, Davidson JA and Hansen PJ (1995) Regulation of prostaglandin secretion and proliferation of bovine endometrial stromal cells by platelet activating factor Reproduction in Domestic Animals 30 141-143

Tiemann U, Neels P, Küchenmeister U, Walzel H and Spitschak M (1996) Effect of ATP and platelet-activating factor on intracellular calcium concentration of cultured oviductal cells from cows Journal of Reproduction and Fertility 108 1-9

Triggle DJ (1990) Calcium, calcium channels, and calcium channel antagonists Canadian Journal of Physiology and Pharmacology 68 1474-1481

Tsien RW (1990) Calcium channels, stores, and oscillations Annual Review of Cell Biology 6 715-760

Velasquez LA, Aguilera JG, Croxatto HB (1995) Possible role of plateletactivating factor in embryonic signaling during oviductal transport in the hamster Biology of Reproduction 52 1302-1306

Wangemann P, Wittner M, Distefano A, Englert HC, Lang HJ, Schlatter E and Greger $\mathbf{R}$ (1986) $\mathrm{Ci}^{-}$channel blockers in the thick ascending limb of the loop of Henle structure activity relationship Pfiugers Archive European Journal Physiology 407 S18-S141

Whitefield JF, Mac Manus JP, Rixon RH, Boynton AL, Youdale AM and 
Swierenga S (1976) The positive control of cell proliferation by the interplay of calcium ions and cyclic nucleotides: a review In Vitro 12 1-18

Wilson HH and Chused TM (1985) Lymphocyte membrane potential and $\mathrm{Ca}^{2+}$ sensitive potassium channels described by oxonol dye fluorescence measurements Journal of Cell Physiology 125 72-78

Yang Y-O, Kudolo GB and Harper MJK (1992) Binding of platelet-activating factor to oviductal membranes during early pregnancy in the rabbit Journal of Lipid Mediators 5 77-96
Yue TL, Gleason MM, Hallenbeck J and Feuerstein G (1991a) Characterization of platelet-activating factor-induced elevation of cytosolic free-calcium level in neurohybrid NCB-20 cells Neuroscience 41 177-185

Yue TL, Gleason MM, Gu J-L, Lysko PG, Hallenbeck J and Feuerstein G (1991b) Platelet-activating factor (PAF) receptor-mediated calcium mobilization and phosphoinositide turnover in neurohybrid NG108-15 cells: studies with BN50739, a new PAF antagonist Journal of Pharmacology and Experimental Therapeutic 257 374-381 